\title{
The role of informational uncertainty in the decision to strategically default
}

\author{
Michael J. Seiler \\ The College of William E' Mary, Mason School of Business, Department of Finance, P.O. Box 8795, Williamsburg, VA 23187-8795, United States
}

\section{A R T I C L E I N F O}

\section{Article history:}

Received 20 January 2015

Accepted 18 February 2015

Available online 28 March 2015

\section{JEL classification:}

D10

D81

K12

K11

R20

\section{Keywords:}

Strategic mortgage default

Informational transparency/opacity

Informational uncertainty

Lender recourse

\begin{abstract}
A B S T R A C T
This study identifies a severe gap between the financial backlash borrowers believe awaits them after strategic mortgage default and the reality that lenders rarely pursue deficiency judgments. This coupled with the social norm finding that borrowers widely view strategic default as immoral, leads us to recommend lenders and policymakers seeking to stem the tide of defaults to pursue a policy of informational opacity. We make several recommendations for how to carry out such a policy as well as what might need to change in society before the alternative policy of informational transparency becomes ideal.
\end{abstract}

(c) 2015 Elsevier Inc. All rights reserved.

\section{Introduction}

Strategic mortgage default is defined as a borrower's unwillingness to make his mortgage payment despite a financial ability to keep his put option alive. ${ }^{1}$ While estimates vary, Guiso et al. (2013), FICO (2011) and Wyman (2010) suggest strategic defaults represent a growing percentage of all defaults, possibly as high as $17 \%-26 \%$.

Note: This study greatly benefitted from the internal review of Christopher M. Clapp, editorial reviews by Keith Ihlanfeldt and Thomas Mayock, as well as participants from the 2014 FSU-OCC symposium. All remaining errors and omissions are my own.

E-mail address: Michael.Seiler@mason.wm.edu

1 Importantly, this differs from an economic default where the borrower is financially unable to afford making his mortgage payment. Economic default is historically triggered by a disruption in household income such as job loss, divorce, a prolonged illness resulting in income curtailment, and so forth, whereas a strategic default is typically triggered by severe negative equity.
Academic and media coverage of the phenomenon is burgeoning as well with most studies focusing on the contagion effect that strategic mortgage default has on both physical neighborhoods and social networks. ${ }^{2}$ To date, no prior study has focused on the role of informational uncertainty surrounding the decision to strategically default.

While mortgage contracts generically address the ramifications associated with non-performance on the part of the borrower, financial life after a mortgage breach is extremely uncertain and varies tremendously from state to state. Indeed, companies such as strategicdefault.org and youwalkaway.com have made a business out of helping strategic defaulters navigate this life-altering decision. Yet, even they have little information to go on given that the current economic environment is unprecedented in

\footnotetext{
2 See studies by Seiler et al. (2014, 2013), Gangel et al. (2013), Harding et al. (2009), Lin et al. (2009) and Rogers and Winter (2009).
} 
our lifetime, that strategic mortgage default did not exist until recently, and that the legal environment, financial, and social ramifications surrounding strategic default continue to evolve. ${ }^{3}$

White (2010) explicitly documents the strong desire of policymakers to stem the tide of strategic mortgage default. ${ }^{4}$ As such, we suggest they consider the role of informational uncertainty. As it relates to the law of incomplete contracts, informational uncertainty refers to evidence that, in the absence of liquidating damages clauses, parties will rely on social norms to guide their behavior (Bicchieri, 2006). Alternatively, when monetary rewards and penalties resulting from a breach of contract are stated in definitive terms, these explicit rules "crowd out" implicit social norms that would otherwise dictate behavior (Gneezy and Rustichini, 2000). Guiso et al. (2013), Seiler et al. (2012) and White (2010) find that society currently views strategic mortgage default as morally objectionable. As a result, if mortgage contracts remain relatively silent on the ramifications of breach, it is reasonable to believe this social norm (not to default) will reign and strategic defaults will be rare. However, if mortgage contracts explicitly address the recourse available to lenders, then borrowers will rely less on social norms and begin to view strategic default as more of a purely economic utility-maximizing decision.

Several studies have documented a reduced social stigma associated with strategic mortgage default. If this trend continues, the ideal amount of information disclosure may shift from a preference on the part of the lender from more to less informational uncertainty in mortgage contracts. To complicate this issue, strategic mortgage default is most likely to occur on outstanding pre-crisis mortgages as opposed to newly originated mortgages for several reasons. Firstly, lending standards are far more stringent in the wake of the financial crisis, thus newer vintage loans are far more conservatively underwritten. ${ }^{5}$ Secondly, a necessary condition for strategic mortgage default is negative equity. New originations all begin with loans being above water (positive equity). As a result, home prices must fall by an amount greater than the borrower's down payment before strategic default is even considered. Even then, studies such as Guiso et al. (2013) document that strategic default is unlikely to occur until a minimum level of $10 \%$ negative equity is experienced. Accordingly, home prices must fall substantially again before loans originated in the post-crisis era will be strategically defaulted upon.

Because outstanding mortgages as opposed to new originations are most susceptible to strategic mortgage default,

\footnotetext{
${ }^{3}$ Until recently, ruthless default - which describes how a homeowner will default the moment he experiences negative equity (becomes underwater on his mortgage) - was only theoretically debated among policymakers.

4 To be clear, we define the goal of policymakers as minimizing the number of borrowers who strategically default. Wheaton and Nechayev (2011) argue that strategic defaults are potentially a market clearing mechanism important to instilling greater discipline on the due diligence of lenders at origination. We leave this debate and subsequent examination of a Pareto optimal solution whose outcome is to maximize overall societal wealth to future studies.

${ }^{5}$ A lack of lending standards leading up to the crisis is well-documented as are more financially conservative lending standards subsequent to the crisis.
}

policymakers need to focus more (at least in the short-run) on the role of informational uncertainty associated with the ex-post ramifications of strategic default rather than on the role of ex-ante mortgage contracts. ${ }^{6}$ Although it is not possible to retroactively go back and alter existing mortgage contracts, it is entirely possible to shape the environment surrounding those who engage in strategic mortgage default moving forward. The purpose of this study is to merge economics with contracts law to better understand the social norms and perceptions surrounding the informationally uncertain environment of strategic mortgage default and make specific policy recommendations to curtail the preference for this course of action moving forward.

Using an on-line experiment involving 1845 homeowners across the United States, we make explicit the quantifiable benefits and consequences associated with strategic mortgage default to half the sample, while the other half of borrowers are only generically described the advantages and disadvantages. We find that the opacity associated with the informational uncertainty trial resulted in significantly fewer defaults. To understand why, we then examine the discrepancy between what borrowers believe to be the quantifiable advantages/disadvantages of strategic default and those that exist in reality. Consistent with Seiler et al. (2012), we find that actual financial backlash pales in comparison to the ex-ante fear and expectation of borrowers.

We are the first to document that the median borrower is willing to pay $\$ 2500$ to keep a strategic default off his credit report. Moreover, the median borrower is only willing to pay $\$ 100$ to keep his friends and family from learning of his strategic default - what we refer to as protecting his reputational capital. ${ }^{7}$ While these drawbacks to strategic default are deemed by our sample of borrowers to be minimal, what is holding them back from defaulting is a staunch belief that the lender will pursue the resulting deficiency judgment. ${ }^{8}$ The median homeowner believes there is a greater than $70 \%$ probability his lender will pursue him for the deficiency amount subsequent to foreclosure. ${ }^{9}$ And while no authority we interviewed could document the true percentage of deficiency judgments that are actually pursued, it is widely held that this number is in the very low single digits. This best kept industry secret is ostensibly predominantly responsible for the fear that is preventing

\footnotetext{
${ }^{6}$ To be clear, we argue that while the results of our investigation are certainly relevant to new originations moving forward, the more pressing, immediate concern surrounds currently outstanding loans as these are the ones more likely to default in the immediate, near term.

7 Even though we document borrower belief that their friends and family would view the default as negative, $43.2 \%$ of borrowers indicated they would not be willing to pay anything to keep their strategic default behavior secret from their social network.

8 This result remains true even after controlling for non-recourse states. Although this may seem surprising on the surface, the result is consisten with Seiler et al. (2012) who find that state laws fail to explain strategic default behavior partly because homeowners are not aware or do not fully understand these laws and partly because the decision to strategically default goes well beyond economic wealth-maximization.

${ }^{9}$ The mode is a $100 \%$ belief that the lender will pursue the deficiency judgment.
} 
countless prospective strategic defaulters from pursing this course of action.

In addition to documenting a belief that the lender will almost always pursue the deficiency judgment (even though they rarely do), we also confirm a strong immorality stance as the social norm. Taken together, the theory of informational uncertainty would suggest it is better at the present time for lenders/policymakers to remain generic/silent as it relates to liquidating damages and specific courses of action taken in the event of breach of contract. Given the severe expectations-reality gap relating to the probability of lender recourse, lenders/policymakers hoping to stem the tide of strategic mortgage default should continue to encourage/promote the immorality of defaulters' action as well as perpetuate the belief that the lender will pursue all deficiency judgments. ${ }^{10}$ Given that it appears the social stigma associated with strategic default may be waning, fear of financial backlash may be all that stands in the way of a major wave of future strategic mortgage defaults.

\section{Breach of contract and morality}

Even though a lengthy legal contract provides more recourse, businessmen had historically preferred to solidify an agreement with a simple handshake or the "giving of one's word" (Macaulay, 1963). Wilkinson-Ryan and Baron (2009), among others, have documented that contract law carries with it an implied promise, and when that promise is broken, the breaching party is viewed as having committed an immoral act. Even when breach benefits the other party, the promisor remains guilty of a transgression in the eyes of the public. As the authors explain, people view a contract as a promise to deliver a particular good or service, not to deliver a financial equivalent to that good or service. When the party who breaches a contract experiences gains from the breach, people seek to provide the promisee with more than "just compensation" for this action, again explained by the fact that the breached party should be compensated not only for the damage caused by the breach, but also for the broken promise. Breach of contract is looked upon in such a negative light in society that often times parties to a contract will not breach even when it is in both parties best interest to do so (i.e., what is known in legal arenas as an efficient breach (Wilkinson-Ryan, 2010)).

\section{Theory of incomplete contracts}

Lorenz (1999) describes that it is not practical or even possible to anticipate all partial performance outcomes, or levels of breach. As such, it is not realistic that a contract can be written to ex-ante resolve how a particular level of breach should be justly compensated. In these (common)

\footnotetext{
10 The Office of the Inspector General of the Federal Housing Finance Authority (FHFA), the supervising agency that oversees Freddie Mac and Fannie Mae, has stated that the agency will pursue all those who abuse FHFA programs. However, they made it clear they are not actively pursuing strategic defaulters. http://www.nationalmortgagenews.com/blogs/compliance/fhfa-oig-placing-mission-in-perspective-1032348-1.html. Accessed on May 31, 2014.
}

situations, courts fill in the gaps of an incomplete contract with social norms - which are based on society's level of expectations of what is reasonable. Because societal standards change over time, so too does the way in which (and the severity with which) courts compensate for various types of breach. This constant evolution can cause a variable lag between laws that are "on the books" and how society would prefer to treat offenders of such laws. $^{11}$

Although surprising on the surface, it can actually benefit a party to intentionally omit from a legal contract recourse actions that would result subsequent to a breach. Consider the documented example of the Boston Fire Department (Wilkinson-Ryan, 2010). Before December of 2001, the Boston Fire Department had no formal policy with regards to sick leave. When a firefighter did not feel well enough to report to work, there was no penalty for taking time off. When the new policy was in place, it allowed for 15 paid sick days a year. Sick days taken beyond the 15 days allowed resulted in a direct reduction in compensation. Pure economic theory would suggest the new policy would result in virtually no firefighter missing any more than 15 days unless absolutely unavoidable. The reality is that firefighter sick days more than doubled their pre-policy period.

It seems that before the formal sick leave policy, the "social norm" among firefighters was to tough it out and go to work no matter how poorly they felt. After the policy was put in place, the perception of sick leave changed from a breach of the social norm to a contractual entitlement. That is, taking a sick day became perfectly acceptable because it was now specifically addressed in their contract. This type of unintended consequence to a new policy occurs regularly and is something policymakers need to be on constant guard to prevent.

\section{Applying incomplete contracts to strategic mortgage default}

\subsection{Supporting incomplete or opaque contracts}

As documented in Guiso et al. (2013) and Seiler et al. (2012), the social norm, or common viewpoint, is that strategic mortgage default is immoral. As previously explained, it is reasonable that strategic default would be viewed as immoral not only because defaulters are breaching their contract, but also because when "breaking this promise" the borrower is leaving the other party (i.e., the lender) worse off. Moreover, because of the well-documented foreclosure spillover or contagion effects, the perception of an immoral act is even greater since defaulting borrowers also negatively impact homeowners around them. As the firefighter example relates to strategic mortgage default, policymakers should consider the possibility that specifying the exact recourse subsequent to breach of a mortgage contract might actually dampen the recourse

\footnotetext{
11 These gaps are often referred to as "loopholes" in the law and are sought out by clever attorneys in an attempt to win cases in which they know they should not emerge victorious.
} 
offered by the court system based on the staunch viewpoint taken by society that strategic default is so immoral.

Cao et al. (2011) offer support for the omission of precisely stated consequences when they discuss the fear of the unknown. The authors state that staying on the "status quo" path (continuing to make our mortgage payments) increases overall utility because a deviation from the status quo carries with it intense feelings of fear of what that alternative might entail (fear of financial backlash in the case of strategic mortgage default). Alternatively explained but offering a consistent conclusion, basic portfolio theory maintains that with increased uncertainty (variance) comes an increase in the required rate of return. Since the return to defaulting on one's mortgage is constant, borrowers will want to avoid the increased risk exposure stemming from a strategic default to their financial wellbeing unless they view the expected return as much greater than staying the current course of action (i.e., continuing to pay their mortgage on time).

\subsection{Supporting complete or transparent contracts}

Wilkinson-Ryan (2010) finds that one benefit resulting from clearly specifying the recourse subsequent to a breach of contract is that it causes parties who might not otherwise think through the various risks inherent with their agreement to deliberately consider not only the potential ramifications, but also assign an economic cost to each outcome. While the mortgage industry is sophisticated enough and has the historical data to quantify various risks associated with loaning money, homeowners might benefit greatly from being encouraged to learn more about the potential risks to homeownership through a more explicit, or transparent, legal contract, because they buy homes so rarely and are almost certainly not trained in economics. If nothing else, a more financially informed borrower should reduce the adverse selection problem on new originations.

The effectiveness of an explicit, or transparent, contract hinges on more than just clearly specifying the ramification to a breach of contract. It is also important to ensure that the recourse offered in the contract exceeds the social norm recourse that the court would rely on in the alternative incomplete, or opaque, contract scenario. Again consider the firefighter example. The reason the more transparent contract had the opposite intended effect is not because transparent contracts are inferior, but is instead because this particular transparent contract carried a non-performance recourse that was less severe than the existing social norm. Had the new contract held that only 7 sick days were allowed or that termination would result after missing " $\mathrm{X}$ " number of days, then it is reasonable to presume fewer, not more, sick days would have been experienced after the new policy was implemented. As such, before policymakers decide whether a transparent or opaque mortgage contract/policy is preferred, it must first be determined whether the current social norm is more or less severe than explicit penalties associated with strategic mortgage default. The next section describes how this perception-reality gap can be measured.

\section{A static model of strategic mortgage default}

Without loss of generality, define utility over a single composite consumption good $(C)$ with a price of $\$ 1$, so $U=U(C)$. Assume individuals are risk averse, so $U^{\prime}(C)>0$, and $U^{\prime \prime}(C)>0$. Conditional on a borrower deciding to strategically default, define expected utility, $E$ (U|default), as the weighted sum of utility across states of the world (indexed by $j$ ). Assume there are two states of the world when an individual defaults: (1) either the lender attempts to recover damages from the borrower $(j=$ bad, from the borrower's perspective) or (2) the lender does not pursue the borrower ( $j=$ good, from the borrower's perspective). This means that $C_{\text {bad }}<C_{\text {good }}$ and $U\left(C_{\text {bad }}\right)<U\left(C_{\text {good }}\right)$ by monotonicity.

Define $\tilde{p}$ as the probability the lender pursues the borrower and $(1-\tilde{p})$ as the probability the lender does not pursue the deficiency judgment. If the borrower decides to strategically default, his expected utility is:

$E(U(C) \mid$ default $)=\tilde{p} U\left(C_{\text {bad }}\right)+(1-\tilde{p}) U\left(C_{\text {good }}\right)$

If a borrower whose home is underwater decides not to default, consumption is known:

$$
\begin{aligned}
E(U(C) \mid \text { no default }) & =U\left(E\left(C_{\text {underwater }}\right)\right) \\
& =U\left(C_{\text {underwater }}\right)
\end{aligned}
$$

where, $C_{\text {bad }}<C_{\text {underwater }}<C_{\text {good }}$.

An individual will strategically default if:

$$
\begin{aligned}
& E(U(C) \mid \text { no default })<E(U(C) \mid \text { default }) \\
& U\left(C_{\text {underwater }}\right)<\tilde{p} U\left(C_{\text {bad }}\right)+(1-\tilde{p}) U\left(C_{\text {good }}\right),
\end{aligned}
$$

and will not default if the inequality is reversed. Eq. (3) describes how the probability of default and relative consumption $\tilde{p}$ and $\left\{C_{\text {bad }}, C_{\text {underwater }}, C_{\text {good }}\right\}$ ) determine this relationship.

\subsection{Risk aversion and reported beliefs}

If a rational, risk averse individual believes $\tilde{p}$ (or the uncertainty surrounding $\tilde{p}$ ) is large and/or $C_{\text {bad }} \ll<<C_{\text {underwater, }}$ that individual will not likely default. Our empirical results will show that borrowers' average expectation of $\tilde{p}$ is that it is closer to $1.0(\hat{p} \cong .70)$ and borrower expectations of consumption are such that $C_{\text {bad }} \ll<C_{\text {underwater. }}$ These findings coupled with the assumption that individuals are risk averse suggest that for most people, $E(U(C) \mid$ no default $)>E(U(C) \mid$ default $)$, which is born out in our data. The intuition for this result can be found by viewing the decision to default through the lens of an insurance problem. Specifically, risk averse individuals are self-insuring against ending in the bad state (where the bank pursues them for the deficiency judgment) by not strategically defaulting. They do so by choosing the certain ourcome, $U$ ( $E$ ( $\left.C_{\text {underwater }}\right)$ ), over the uncertain outcome, $E(U(C) \mid$ default).

\section{Data collection effort}

We access the same general pool of homeowners as in Seiler et al. (2012, 2014) and Seiler (2014), among others. 
Specifically, we posted a Human Intelligence Task (HIT) on MTurk asking people from across the country to participate in a study relating to the housing market. ${ }^{12}$ Our purpose was to intentionally remain vague so as not to communicate the underlying hypotheses we test and to avoid sample selection bias. Respondents were told they would be paid $\$ 1.07$ for participation that would require 5-8 $\mathrm{min}$ of their time. $^{13}$

We collected a total of 2000 responses, and then used the screening process described below to arrive at our final sample of 1845 complete and usable responses. One scrubber we use is a hidden timer placed behind every screen that measures to the millisecond exactly how long each participant stayed on the page. This provides insight into whether or not the participant took the time to read the scenario. As a further screen, we dispersed two simple questions asking participants to select, say "4," and then disqualify any participant whose answer does not match our request.

Continuing, we begin the process by asking participants to select their location from a state and then city dropdown menu. Then, towards the end of the experiment, we ask them for their 5-digit zip code. By cross referencing the two entries, we can determine if they were either careless or incorrect in reporting accurate and consistent information. Finally, this clearinghouse system allows researchers to provide feedback relating to the (un)successful performance of respondents on current tasks. As a front-end filter, we only allow subjects to see our posting who have at least a 95\% historic approval rating from past HITs. It is worthy to note that it is in our best research interest to properly screen respondents because failing to properly do so would work towards a null result.

\section{Hypothesized relations}

As previously described, we employ an on-line experimental framework and create two treatments where the only variant between the treatments is the role of informational uncertainty. Specifically, we begin by creating a consistent hypothetical environment described as follows:

Imagine you bought your primary residence (the home you own and live in full-time) four years ago at a price of $\$ 300,000$. Since then, the price of your home has dropped dramatically. You are considering strategically defaulting on your mortgage based on the following information. Strategic Default is when you stop paying your mortgage even though you can afford to continue making payments.

\section{Assume the following:}

(1) You have a fixed rate mortgage and can afford to continue making your $\$ 2100 /$ month mortgage payment.

\footnotetext{
12 Pre-qualified participants are allowed into the experiment on a first come basis and are assured anonymity via a clearinghouse system where only worker ID numbers are conveyed to the researcher.

13 Since there is no right or wrong answer to our questions, it makes sense to pay a flat rate participation fee as opposed to a variable rate - which is used when there are "correct" answers.
}

(2) You do not expect the price of your home to change over the next 4 years.

(3) Because of the drop in home prices, if you were to sell your home today and attempt to pay off your mortgage, you would still owe $\$ 100,000$ to your lender.

We then explicitly described the benefits and consequences of strategic mortgage default to the "Informationally Transparent" pool of homeowners as follows:

Benefits to Strategic Default:

(1) You will live in the house rent free for the next $<6$; $12 ; 18 ; 24 ; 30 ; 36>$ months.

(2) You hope the bank will not come after you for the amount you will still owe the lender after they foreclose and sell off your house.

\section{Consequences to Strategic Default:}

(1) After the lender takes your house, your credit score will be reduced by roughly 150 points making it both more difficult and more expensive to borrow money for the next $\langle 2 ; 5 ; 7 ; 10>$ years.

(2) You will have to pay the cost of relocating to a new residence.

(3) There is a $<90 \% ; 50 \% ; 10 \%>$ chance the lender will come after you for the $\langle 6 ; 12 ; 18 ; 24 ; 30 ; 36\rangle$ months of missed mortgage payments and the amount you still owe them on the mortgage after they foreclose and sell off your house.

To the "Informationally Opaque" pool of homeowners, we generically described strategic default considerations as follows:

The list of financial benefits and consequences are extremely uncertain surrounding a strategic default. Potential benefits might include being able to live in the house rent free for some period of time and the hope the lender will not come after you for the money you will still owe them after they foreclose and sell off your house.

Potential consequences to strategic default include a substantially reduced credit score for some number of years making it more difficult and expensive to borrow in the future, having to move yourself, and the risk the lender will come after you for the missed mortgage payments and the money you still owe them on the mortgage after they foreclose and sell off your house.

On a scale from 1 (Definitely will NOT Default) to 8 (Definitely WILL Default), we then ask borrowers how likely they are to default in this situation. This likelihood of strategic default serves as our primary (dependent) variable of interest in the study. Concerning potential explanatory (independent) variables, note that the numbers within the "<>" represent randomly generated/inserted values that vary among our 1,845 homeowner participants. Based on our list of benefits and consequences, we vary the probability of lender recourse, months before the lender will force vacating the property, and the number of years the strategic default will remain on the borrower's 
credit report. In the informationally transparent treatment, these specific numbers are provided, whereas in the informationally opaque trial, they are only alluded to.

Probability of lender recourse is expected to carry a negative relation with willingness to strategically default because borrowers will not default if they know the lender will come after them for the deficiency judgment. Months before forced vacation of the property would have a positive sign in that the borrower hopes to live rent free for a longer period of time, but could be negative if they believe the lender will come after them and eventually collect the retroactive mortgage payments plus penalties and interest. As a result, we leave this sign as an open empirical question. Finally, years the default will remain on the credit report is expected to have a negative sign as borrowers would prefer the negative impact on their credit report be removed sooner rather than later.

Based on Guiso et al. (2013) and FICO (2011), we collect additional potential independent variables by asking, "To what degree do you think it is moral to Strategically Default in this situation?" collecting this measure on an 8 -point scale ranging in values from 1 (Not Moral at all) to 8 (Completely Moral). We expect a positive relation meaning that people who view strategic default as immoral are less likely to strategically default. Motivated by Seiler (2014), we then ask borrowers who is more to blame for the current housing crisis on a scale from 1 (Lenders are more to blame) to 9 (Borrowers are more to blame). Homeowners who blame lenders are hypothesized to be more willing to walk away.

White (2012) provides a lengthy discussion of how, in an effort to improve homeownership rates in the United States, the federal government promoted residential real estate as an investment opportunity superior to virtually all other savings vehicles, and argues that as a result, US residents purchased homes for the wrong reasons. Now that those "investments" have gone bad, White argues that homeowners are more willing to walk away than are residents who view their home as more of a consumption good. Because the average owner does not have a command over the definition of a consumption versus investment good, we ask the question as follows, "Do you view your primary residence (where you live) as more of an "investment" or more of a "home?" on a scale from 1 (More as an "Investment") to 9 (More as a "Home"). Consistent with White (2012), we anticipate a positive sign for those who view their home as more of an investment.

Consistent with Seiler et al. (2012), we further ask if the borrower has ever previously defaulted on a mortgage. Those who have defaulted in the past are expected to be more willing to do so again in the future. As such, a positive sign is anticipated. Finally, a series of demographic variables are included (where econometrically allowed) such as gender, marital status, age, income, net worth, and ethnicity.

\section{Results}

Our central hypothesis is that strategic default willingness is dependent upon informational uncertainty. The finding of a null result would mean (1) informational uncertainty is not a determinant of strategic mortgage
Table 1

Mean likelihood of strategic default by probability of lender recourse.

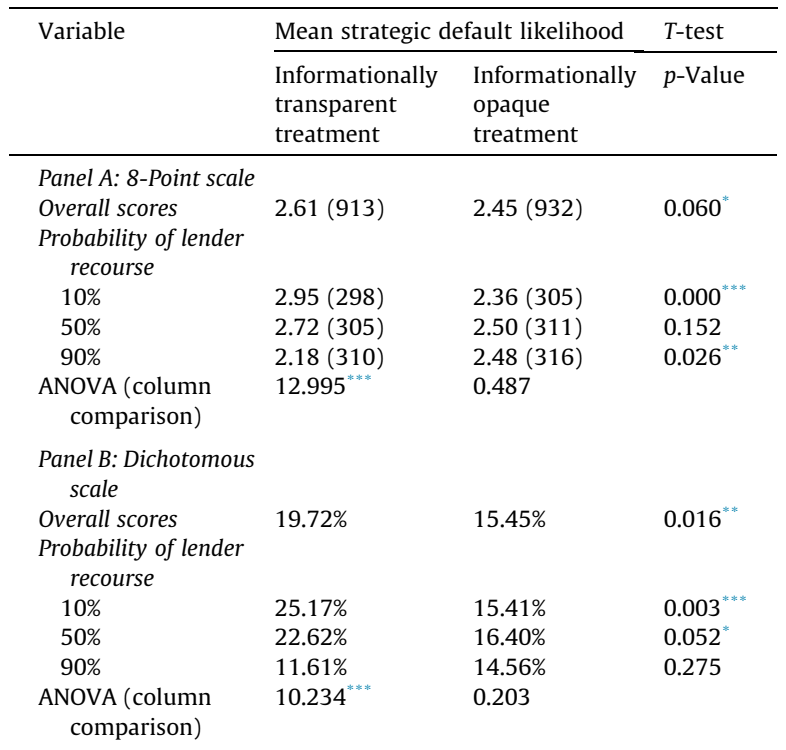

This table reports the mean likelihood of lender default when the probability of lender recourse changes from a very low $(10 \%)$ to a very high $(90 \%)$ percentage. Panel A refers to the default likelihood when represented on an 8 -point scale where $1=$ definitely will not default and $8=$ definitely will default, while Panel B represents willingness to strategically default as a dummy variable. The informationally transparent benefits and consequences column refers to the trials where subjects are told the probability of lender recourse. By way of comparison, the informationally opaque column only qualitatively describes what could happen following a strategic default. T-stats in the final column test for differences in the mean between these two columns. ANOVA tests in each panel test for collective group differences across the three probabilities of lender recourse (10\%; $50 \%$; $90 \%$ ) within each column and panel separately.

* Indicates statistical significance at the $90 \%$ level.

** Indicates statistical significance at the $95 \%$ level.

${ }_{* * *}^{*}$ Indicates statistical significance at the $99 \%$ level.

default and/or (2) borrower expectations are consistent with reality. In Table 1, we see that no matter how we scale willingness to strategically default (on either an 8-point scale or as a dichotomous variable), variation within the informationally transparent treatment mean scores is statistically significant, whereas this is not the case in the informationally opaque treatment. This allows us to conclude, in a univariate sense, that informational uncertainty matters. That the informationally transparent results are robustly significant, whereas the informationally opaque treatment column is not significant also confirms that participants in the experiment were paying close attention to our treatment effects.

To understand why informational uncertainty matters, we next turn to an investigation of homeowner expectations surrounding the reaction of various parties to a strategic default. In Panel A of Table 2, homeowners are asked the question, "If you were to stop paying your mortgage today, how many months would pass before your home would be foreclosed upon and you would be forced to leave?" Nearly $60 \%$ believe they would have to vacate the home within six months of their first missed mortgage payment. While Ghent and Kudlyak (2011) demonstrate 
Table 2

Homeowner expectations following a strategic mortgage default.

\begin{tabular}{|c|c|c|c|}
\hline Homeowner expectations & $\begin{array}{l}\text { Informationally transparent } \\
\text { treatment }\end{array}$ & $\begin{array}{l}\text { Informationally opaque } \\
\text { treatment }\end{array}$ & $\begin{array}{l}\text { Combined cumulative } \\
\text { percentages }\end{array}$ \\
\hline Panel A: Months before lender recourse & $N=913$ & $N=932$ & $N=1845$ \\
\hline $0-6$ months & $58.8 \%$ & $59.5 \%$ & $59.7 \%$ \\
\hline $0-12$ months & $86.4 \%$ & $85.6 \%$ & $86.2 \%$ \\
\hline $0-18$ months & $91.1 \%$ & $90.9 \%$ & $90.9 \%$ \\
\hline $0-24$ months & $95.1 \%$ & $95.7 \%$ & $95.4 \%$ \\
\hline $0-30$ months & $95.9 \%$ & $97.0 \%$ & $96.4 \%$ \\
\hline 0-36 months & $97.5 \%$ & $98.7 \%$ & $98.1 \%$ \\
\hline $0-42$ months & $97.6 \%$ & $98.7 \%$ & $98.2 \%$ \\
\hline Longer than 42 months & $\begin{array}{l}100.0 \% \\
Z=-0.150(p=0.881)\end{array}$ & $100.0 \%$ & $100.0 \%$ \\
\hline \multicolumn{4}{|l|}{ Panel B: Reaction from family/friends } \\
\hline Percentage viewed negatively & $79.2 \%$ & $79.1 \%$ & $79.1 \%$ \\
\hline Percentage viewed neutrally & $16.6 \%$ & $16.2 \%$ & $16.4 \%$ \\
\hline Percentage viewed positively & $\begin{array}{l}4.2 \% \\
Z=-0.393(p=0.694)\end{array}$ & $4.7 \%$ & $4.5 \%$ \\
\hline \multicolumn{4}{|l|}{ Panel C: Probability of lender recourse } \\
\hline $0 \%$ & $3.0 \%$ & $3.6 \%$ & $3.3 \%$ \\
\hline $10 \%$ & $6.9 \%$ & $4.4 \%$ & $5.6 \%$ \\
\hline $20 \%$ & $10.1 \%$ & $7.3 \%$ & $8.7 \%$ \\
\hline $30 \%$ & $14.6 \%$ & $11.5 \%$ & $13.0 \%$ \\
\hline $40 \%$ & $16.9 \%$ & $13.8 \%$ & $15.3 \%$ \\
\hline $50 \%$ & $29.5 \%$ & $21.9 \%$ & $25.6 \%$ \\
\hline $60 \%$ & $35.8 \%$ & $28.1 \%$ & $31.9 \%$ \\
\hline $70 \%$ & $50.8 \%$ & $42.3 \%$ & $46.5 \%$ \\
\hline $80 \%$ & $64.5 \%$ & $60.5 \%$ & $62.5 \%$ \\
\hline $90 \%$ & $80.0 \%$ & $73.6 \%$ & $76.7 \%$ \\
\hline $100 \%$ & $\begin{array}{l}100.0 \% \\
Z=-3.748(p=0.000)^{* * *}\end{array}$ & $100.0 \%$ & $100.0 \%$ \\
\hline
\end{tabular}

This table reports homeowner expectations following a strategic mortgage default. Panel A reflects borrower beliefs concerning how many months would pass between a first missed mortgage payment and when a resulting foreclosure process would force the person to vacate the home. Panel B measures anticipated severity of reactions from family and friends, while Panel C refers to the borrower's estimate of the probability that the lender would come after them for the resulting deficiency judgment. Mann-Whitney U tests compare distributions between each treatment for each of the three panels.

* Indicates statistical significance at the $90 \%$ level.

*** Indicates statistical significance at the $95 \%$ level.

*** Indicates statistical significance at the $99 \%$ level.

$p$-Values are reported inside the parentheses.

this tenure length certainly varies by state, it has tended to lengthen during the financial crisis. ${ }^{14}$

In Panel B, 95.5\% of those within the borrowers' social network view strategic default as negative $(79.1 \%)$ or neutral (16.4\%). Finally, in Panel C, perceptions of probability of lender recourse are collected. Almost no one $(3.6 \%)^{15}$ believes borrowers will get away with defaulting on their loan. Interestingly, the most common belief (the mode) is that there is a $100 \%$ chance the lender will come after the

\footnotetext{
$\overline{14}$ Harrison and Seiler (2015) find that length of tenure in a home following a notice of intent to foreclose is primarily due to differences in power-of-sale versus judicial foreclosure proceedings. Each state is left to determine which process they will adopt.

${ }^{15}$ When discussing Panel $\mathrm{C}$ results, we now refer to the numbers from the opaque treatment as their distribution of percentages significantly differs from that of the transparent treatment. One potential explanation as to why these two columns might differ is that previously seeing our tested probabilities of lender recourse $(10 \%, 50 \%$, and $90 \%)$ in the transparent treatment may have swayed the (subconscious) opinion of borrowers when we asked them this subsequent question. This supposition would not explain why column values in Panel A do not significantly differ across treatment effects. However, this observation would be consistent with the well-documented anchoring literature. Still, to be conservative, while we provide full results in Table 2, we discuss in the text only the opaque results from Panel $\mathrm{C}$ which we know cannot suffer from anchoring bias (since the borrower never saw the $10 \%, 50 \%$, and $90 \%$ lender recourse values).
}

borrower. In fact, $71.9 \%$ (100\% - 28.1\%) of sampled borrowers believe there is at least a $60 \%$ probability the lender will come after them if they default. ${ }^{16}$ Although we asked several sources within the government, lending industry, and legal system to identify the true percentage of pursued deficiency judgments, no one could definitely cite a number. Yet, all believe it is in the low single digits. ${ }^{17}$ This disparity between perception and reality is striking to say the least.

To further investigate whether the probability of lender recourse is responsible for differential stated willingness to strategically default, we turn back to Table 1 . In Panel A, where the 8-point scale is used, strategic default willingness scores are segmented by three levels of probability of lender default: $10 \%, 50 \%$, and $90 \%$. Reading down the informationally transparent column (where these probabilities were reported to the borrower during the treatment), we see a steady, statistically significant decrease in willingness to strategically default as the probability of lender recourse increases. Using an ANOVA to test for

\footnotetext{
16 The mean belief is over $70 \%$.

17 One source who asked to remain anonymous stated that, to the best of their knowledge, only 20 of their 7000 strategic defaulting clients have been pursued after strategically defaulting.
} 
differences across the three probabilities, we see an $F$ statistic that is significant well beyond the $99 \%$ level of confidence. Since the probabilities in the informationally opaque column were generated automatically by the program code, but not reported to the borrowers, there is no hypothesis associated with differentially reported willingness to default scores here. Instead, we can simply refer to the overall willingness in this treatment of 2.45. If the 2.45 value is placed along the scale of those who actually saw a probability of $10 \%$ (2.95), $50 \%$ (2.72), or $90 \%$ (2.18), we see that the 2.45 falls somewhere between the $50 \%$ (2.72) and 90\% (2.18) probability scenarios. Recalling from Table 2 that the median belief of lender recourse is just above $70 \%$, when taken together, the two tables appear to converge to explain that the perception-reality gap in lender recourse is responsible (at least in a univariate sense, for now) for borrowers' hesitancy to strategically default. The same reasoning and conclusion can be applied to the data in Panel B of Table 1 as well, where stated willingness to strategically default is measured as a dummy variable.

Before moving on to a multi-variate investigation, we first examine the potential list of independent variables used in the regression analysis. Table 3 reports mean/median, standard deviation, minimum, and maximum values for each potential independent variable. The first section refers to Micro Perspective Variables meaning that they relate in a very specific and personal way to the borrower. As previously stated, the mean probability of lender recourse belief is over $70 \%$, while the median belief surrounding forced vacancy of the property is 6 months. The variable reputational capital has two associated measures. The first is the 9-point scale previously mentioned which has a mean value of 2.65 indicating a generally negative social norm with regards to strategic mortgage default. The second measure attempts to more properly put into perspective how much this negative social backlash impacts potential defaulting borrowers through a reduction in reputational capital. If fear of being shunned by one's social network is an inhibitor to strategic default, then one way to measure this impact is to ask borrowers "What is the maximum amount you would be willing to pay to keep your friends and family from learning you strategically defaulted on your mortgage?" To our knowledge, we are the first to quantify the cost associated with strategic default from a reputational capital standpoint. Forty-three point two (43.2\%) percent of borrowers in our sample are not willing to pay anything to prevent their friends and family from finding out they strategically defaulted on their mortgage. Moreover, the median willingness to pay is only $\$ 100$. While this might seem surprising on the surface, Seiler et al. (2012) report that half of strategic defaulters voluntarily told their family they defaulted by choice, whereas other people were either not told at all or told it was an economic default.

To quantify the negative impact strategic default has on one's credit report, we again use a traditional economic willingness-to-pay (WTP) measure to once more be the first to make a contribution on this front. By asking "If you had an "Excellent" credit rating, what is the maximum amount you would be willing to pay in order to prevent your credit from dropping down into the "Poor" credit rating range if having "Poor" credit made it both more difficult and more expensive to borrow money for the next $<2 ; 5 ; 7 ; 10>$ years?," The median willingness to pay to protect a borrower's credit score is $\$ 2500$.

The first Macro Perspective Variable we consider is morality. The mean morality score is 2.82 indicating a social norm being of the opinion that strategic default is not moral. This is consistent with extant real estate and legal studies previously cited. Whether the homeowner blames lenders versus homeowners for the current housing crisis is measured on both an 8-point scale and as a dummy variable. Roughly half (50.9\%) the sample blames lenders more than borrowers for the current crisis. Concerning the consumption versus investment motive, the mean score of 7.23 reveals that homeowners in our sample view their home as more of a consumption good as opposed to an investment. Finally, only $4.3 \%$ of our sample of borrowers has previously defaulted on a mortgage. Of those, $10.1 \%$ were strategic in nature.

Demographic data is reported in the final panel. Males compose $50.8 \%$ of the sample, while married borrowers represent $61.3 \%$. The mean age is 37.26 years and ranges from 18 to 84 . Annual income is measured on a 7-point scale with a mean of 3.51 , or approximately $\$ 70,000$. Positive net worth is associated with $66.0 \%$ of the sample who are ethnically diversified as follows: Caucasian (83.2\%), African Americans (4.6\%), Hispanic (4.0\%), Asian (4.8\%), and other (2.1\%). In sum, our sample of homeowners is consistent with the national statistics reported in the American Housing Survey and American Community Survey who report: White (81.0\%), Black (8.0\%), Hispanic (3.1\%), and Asian (7.9\%); 52.3\% are married; homeowner income is $\$ 60,000$; age is 52 ; as well as past studies that have accessed this general pool of homeowners.

To examine our hypotheses in a multi-variate context, Table 4 reports the results from regressions where the dependent variable is the stated willingness to strategically default and the independent variables are as described in Table 3. The first model reports results for the pool of homeowners within the informationally transparent treatment. Because these borrowers were provided with specific quantitative benefits/consequences values, we use the randomly generated numbers embedded within those scenarios as independent variables. As hypothesized, three of the four micro perspective variables (probability of lender recourse, months before possession, and reputational capital) all carry the proper sign and are significant at the 99\% level. The only variable that is not significant (but still carries the proper sign) is the impact on credit report. Specifically, the finding implies that whether the borrower's default appears on his credit report for $2,5,7$, or 10 years, the result has a non-significant effect on his decision to strategically default. ${ }^{18}$

\footnotetext{
18 To clarify, this is not to say that having a derogatory mark on one's credit report does not concern the borrower. But rather, the length of time the derogatory mark remains on the credit report is not differentially statistically significant. To test for the effect of the presence versus absence of a derogatory mark on a credit report, we would have had to create a scenario where no mark resulted from the default and tested that absence against the scenarios were a derogatory mark did get reported to the credit bureaus. In such a test, it would seem reasonable to hypothesize that those who plan to use credit in the future would be less willing to strategically default than "transactors" who fully pay off their debts each month.
} 
Table 3

Univariate summary statistics.

\begin{tabular}{|c|c|c|c|c|c|}
\hline Variable & Obs. & Mean/median & Std. dev. & Minimum & Maximum \\
\hline \multicolumn{6}{|l|}{ Micro perspective variables } \\
\hline Probability of recourse & 1845 & 8.11 & 2.72 & 1 & 11 \\
\hline Months before possession & 1845 & 6 & 8.52 & 1 & 48 \\
\hline \multicolumn{6}{|l|}{ Impact on credit report } \\
\hline WTP/WTA - Credit Protection & 1845 & $\$ 2,500$ & & & \\
\hline \multicolumn{6}{|l|}{ Reputational capital } \\
\hline WTP/WTA - Friends & 1845 & $\$ 100$ & & & \\
\hline How friends will view SD & 1845 & 2.65 & 1.71 & 1 & 9 \\
\hline \multicolumn{6}{|l|}{ Macro perspective } \\
\hline Morality & 1845 & 2.82 & 2.05 & 1 & 8 \\
\hline \multicolumn{6}{|l|}{ Blames the lender } \\
\hline 9-point scale & 1845 & 3.95 & 1.93 & 1 & 9 \\
\hline Dichotomous scale & 1845 & $50.9 \%$ & 0.50 & 0 & 1 \\
\hline \multicolumn{6}{|l|}{ Home as an investment } \\
\hline 9-point scale & 1845 & 7.23 & 2.00 & 1 & 9 \\
\hline Dichotomous Scale & 1845 & $6.78 \%$ & 0.25 & 0 & 1 \\
\hline Previous default & 1845 & $4.3 \%$ & 0.20 & 0 & 1 \\
\hline Economic default & 71 & $89.9 \%$ & & & \\
\hline Strategic default & 8 & $10.1 \%$ & & & \\
\hline \multicolumn{6}{|l|}{ Demographics } \\
\hline Male dummy & 1845 & $50.8 \%$ & 0.50 & 0 & 1 \\
\hline Married dummy & 1845 & $61.3 \%$ & 0.49 & 0 & 1 \\
\hline Age & 1845 & 37.26 & 11.18 & 18 & 84 \\
\hline Income & 1757 & 3.51 & 1.50 & 1 & 7 \\
\hline Positive net worth dummy & 1646 & $66.0 \%$ & 0.47 & 0 & 1 \\
\hline Ethnicity & 1820 & & & & \\
\hline Caucasian & 1535 & $84.4 \%$ & & & \\
\hline African American & 84 & $4.6 \%$ & & & \\
\hline Hispanic & 74 & $4.1 \%$ & & & \\
\hline Asian & 88 & $4.8 \%$ & & & \\
\hline Other & 39 & $2.1 \%$ & & & \\
\hline
\end{tabular}

This table reports univariate summary statistics for variables considered in the regression analysis. Micro perspective variables include the average probability of lender recourse (on a scale from $1=0 \%$, to $11=100 \%$ ); the average number of months the homeowner expects to be able to stay in the home after missing the first mortgage payment (capped at 48 months); reputational capital effects including two measures: how friends will view SD on average (on a scale from 1 = they would view it negatively, to 9 = they would view it positively), and the median of either the person's maximum Willingness-to-Pay (WTP) to prevent friends from learning of their default or median minimum Willingness-to-Accept (WTA) to prevent friends from learning of their default (the sample was randomly assigned one or the other method of framing the question). Finally, the impact on one's credit score was measured in the same way as the WTP and WTA methods except now we are measuring the person's median willingness to avoid a negative impact on their credit score. Macro perspective variables include the homeowner's assessment of the morality of strategic default (on a scale from $1=$ not moral at all, to $8=$ completely moral); Blames the Lender is measured on both a 9-point scale (where $1=$ the lender is more to blame for the current housing crisis, and $9=$ the borrower is more to blame); This variable is also converted into a dummy variable for whether the respondent more so blames the lender (=1) as opposed to the borrower (=0) for the current housing crisis; A similar pair of variables is collected relating to whether the homeowner views his home as an investment ( 1 on a scale from 1 to 9 ) as opposed to a consumption good ( 9 on a scale from 1 to 9 ); Home as an Investment dummy $=1$ for more of an investment and = 0 for more of a consumption good. Finally, Previous Default $=1$ if the respondent previously defaulted on a mortgage, 0 otherwise. Of those who have defaulted respondents self-select into whether the default was economic or strategic in nature. Demographic variables include gender; marital status; age; ethnicity; income on a scale from $1=$ under $\$ 20,000$, to $7=$ over $\$ 120,000$; and a dummy where positive net worth $=1$, 0 otherwise. Finally, ethnicity is reported by category.

Within the macro perspective set of explanatory variables, morality is the most robust, followed by the blames the lender dummy, and the previous default dummy. Whether the homeowner views his home as more of an investment versus more of a consumption good did not impact his willingness to walk away from his home. Among demographic variables, both being married and being older are significantly associated with a lesser willingness to strategically default. ${ }^{19}$ The model's overall metrics signify a robust specification as the adjusted $R^{2}$ is .279 , and the F-statistic is a robust 36.28 , significant well beyond the $99 \%$ level. The second model reported in Table 4 reports only the remaining significant variables from Model I. A

\footnotetext{
19 The remaining demographic variables were excluded for various reasons such as excessive correlations, lost observations, and so forth.
}

cursory glance reveals stability in both values and significance levels across the two models.

Model III is reported to allow a transition from the transparency treatment sub-sample to the full sample set and central hypothesis testing. Specifically, since only the transparency treatment participants saw specific variables for probability of lender recourse and months they would be able to reside in the property after failing to make their mortgage payments, we use Model III to replace transparency treatment variables with the variables experienced by all our participants, not just those in the transparency sub-pool. For the sake of brevity, we quickly summarize by stating that the stability in both coefficients and signs between Models II and III are highly robust. This offers statistical support for our transition to including the full sample in Model IV. 
Table 4

Regression results explaining likelihood of strategic default.

\begin{tabular}{|c|c|c|c|c|}
\hline & $\begin{array}{l}\text { Model I } \\
\text { Initial model }\end{array}$ & $\begin{array}{l}\text { Model II } \\
\text { Final model }\end{array}$ & $\begin{array}{l}\text { Model III } \\
\text { Final Model using replacement variables }\end{array}$ & $\begin{array}{l}\text { Model IV } \\
\text { Full sample model }\end{array}$ \\
\hline $\begin{array}{l}\text { Independent variables } \\
\text { Intercept }\end{array}$ & $\begin{array}{l}2.362^{* * *} \\
(0.328)\end{array}$ & $\begin{array}{l}2.219^{* * *} \\
(0.293)\end{array}$ & $\begin{array}{l}2.660^{* * *} \\
(0.299)\end{array}$ & $\begin{array}{l}2.456^{* * *} \\
(0.209)\end{array}$ \\
\hline $\begin{array}{l}\text { Micro perspective } \\
\text { Probability of recourse }\end{array}$ & $\begin{array}{l}-0.325^{* * *} \\
(0.067)\end{array}$ & $\begin{array}{l}-0.320^{* * *} \\
(0.067)\end{array}$ & $\begin{array}{l}-0.094^{* * * *} \\
(0.021)\end{array}$ & $\begin{array}{l}-0.94^{* * *} \\
(0.014)\end{array}$ \\
\hline Months before possession & $\begin{array}{l}0.089^{* * *} \\
(0.032)\end{array}$ & $\begin{array}{l}0.091^{* * * *} \\
(0.032)\end{array}$ & $\begin{array}{l}0.013^{* *} \\
(0.006)\end{array}$ & $\begin{array}{l}0.002 \\
(0.004)\end{array}$ \\
\hline Reputational capital & $\begin{array}{l}0.112^{* * *} \\
(0.036)\end{array}$ & $\begin{array}{l}0.114^{* * *} \\
(0.036)\end{array}$ & $\begin{array}{l}0.098^{* * *} \\
(0.036)\end{array}$ & $\begin{array}{l}0.143^{* * *} \\
(0.025)\end{array}$ \\
\hline Years on credit report & $\begin{array}{l}-0.056 \\
(0.048)\end{array}$ & & & \\
\hline Macro perspective & & & & \\
\hline Morality & $\begin{array}{l}0.369^{* * *} \\
(0.031)\end{array}$ & $\begin{array}{l}0.369^{* * *} \\
(0.031)\end{array}$ & $\begin{array}{l}0.352^{* * *} \\
(0.031)\end{array}$ & $\begin{array}{l}0.320 * * * \\
(0.021)\end{array}$ \\
\hline Blames the lender & $\begin{array}{l}0.251^{* *} \\
(0.111)\end{array}$ & $\begin{array}{l}0.248^{* *} \\
(0.111)\end{array}$ & $\begin{array}{l}0.211^{*} \\
(0.112)\end{array}$ & $\begin{array}{l}0.170^{* *} \\
(0.076)\end{array}$ \\
\hline Home as an investment & $\begin{array}{l}0.214 \\
(0.220)\end{array}$ & & & \\
\hline Previous default & $\begin{array}{l}0.488^{*} \\
(0.267)\end{array}$ & $\begin{array}{l}0.482^{*} \\
(0.267)\end{array}$ & $\begin{array}{l}0.453^{*} \\
(0.269)\end{array}$ & $\begin{array}{l}0.474^{* *} \\
(0.187)\end{array}$ \\
\hline Demographics & & & & \\
\hline Married dummy & $\begin{array}{l}-0.389^{* * * *} \\
(0.114)\end{array}$ & $\begin{array}{l}-0.391^{* * * *} \\
(0.114)\end{array}$ & $\begin{array}{l}-0.369^{* * *} \\
(0.114)\end{array}$ & $\begin{array}{l}-0.251^{* * *} \\
(0.077)\end{array}$ \\
\hline Age & $\begin{array}{l}-0.340^{* * *} \\
(0.113)\end{array}$ & $\begin{array}{l}-0.346^{* * *} \\
(0.112)\end{array}$ & $\begin{array}{l}-0.372^{* * *} \\
(0.112)\end{array}$ & $\begin{array}{l}-0.336^{* * *} \\
(0.076)\end{array}$ \\
\hline $\begin{array}{l}\text { Central hypothesis test } \\
\text { Transparency treatment dummy }\end{array}$ & & & & $\begin{array}{l}0.161^{* *} \\
(0.075)\end{array}$ \\
\hline Observations & 913 & 913 & 913 & 1,845 \\
\hline F-statistic & 36.28 & 45.05 & 44.01 & 79.56 \\
\hline$p$-value & $0.000^{* * *}$ & $0.000^{* * *}$ & $0.000^{* * *}$ & $0.000^{* * * *}$ \\
\hline Adjusted $R^{2}$ & 0.279 & 0.279 & 0.274 & 0.277 \\
\hline
\end{tabular}

This table reports the results from four regressions where the dependent variable is the stated likelihood of strategic mortgage default on an 8-point scale where $1=$ definitely will not default, and $8=$ definitely will default. Micro Perspective variables include the probability of lender recourse (where $1=10 \%$, $2=50 \%$, and $3=90 \%$ in Models I and II; and on a scale from $1=0 \%$ through $11=100 \%$ in Models III and IV); the number of months the homeowner expects to be able to stay in the home after missing the first mortgage payment (where $1=6$ months through $6=36$ months for Models I and II, and in Models III and IV the respondent specifies a number - which is subsequently capped at 48 months); reputational capital is measured as how friends will view SD on average (on a scale from 1 = they would view it negatively, to $9=$ they would view it positively). Finally, years on credit report values are assigned as $1=2$ years, $2=5$ years, $3=7$ years, and $4=10$ years. Macro perspective variables include the homeowner's assessment of the morality of strategic default (on a scale from $1=$ not moral at all, to $8=$ completely moral); Blames the Lender is measured as a dummy variable where $1=$ the respondent more so blames the lender, 0 otherwise; Home as an Investment $=1$ when the homeowner views his home as more of an investment, and $=0$ when it is viewed as more of a consumption good. Finally, Previous Default $=1$ if the respondent previously defaulted on a mortgage, 0 otherwise. Demographic variables include a married dummy where 1 = married, 0 otherwise; and age. Finally, the transparency treatment dummy variable $=1$ for those in the transparency treatment and $=0$ for those in the opacity treatment.

" Indicates statistical significance at the $90 \%$ level.

** Indicates statistical significance at the $95 \%$ level.

*** Indicates statistical significance at the $99 \%$ level. Standard errors are reported inside the parentheses.

The central hypothesis of this study is to test whether it is more advisable for policymakers to follow a method of transparency versus one of opacity (borrowing from the theory of incomplete contracts in the field of law). To put a fine point on this test, we draw attention to the very last row in Model IV. Specifically, the variable Transparency Treatment Dummy is equal to 1 for those in the transparency treatment and 0 for those in the opacity treatment. The observation of a positive and significant sign on this variable means opacity leads to a statistically significantly lesser likelihood of strategic mortgage default. Overall, Model IV is robust with an adjusted $R^{2}$ of .277 and an F-statistic of 79.56, significant well beyond the 99\% level. Thus, subject to the limitations of any experiment (such as applicability outside the lab and generalizability of the results), we suggest policymakers follow an opacity strategy at this time. ${ }^{20}$

\section{Conclusions}

This study uses the theory of informational uncertainty to examine whether having more transparent information

\footnotetext{
$\overline{20}$ The results are robust to alternative model specifications.
} 
surrounding the strategic mortgage default decision makes default more or less likely. We find that homeowners perceive the financial backlash from lenders, particularly the probability of lender recourse, to be far more severe than in actuality. As a result, borrowers are extremely reluctant to default for fear of reprisal. Supporting the continued payment of one's mortgage is the social norm which maintains that strategic mortgage default is immoral. Taken together, our results imply that lenders and policymakers who wish to prevent strategic defaults from gaining in communality should heavily promote and even extend the belief that strategic defaulters will be pursued by lenders. This can be done through various campaigns, heavy media coverage of select high profile cases, or lenders actually pursuing deficiency judgments.

We are the first to quantify two of the consequences of strategic mortgage default. Specifically, we find that the median willingness to pay by borrowers to keep a strategic default off their credit report is $\$ 2500$. Interestingly, the willingness of borrowers to pay to prevent their friends from learning of their strategic default (reputational capital) is only $\$ 100$, with $43.2 \%$ of borrowers not willing to pay anything to protect this secret. Clearly, the social stigma attached to strategic mortgage default is waning, possibly as this course of action becomes increasingly more common.

As explained by the theory of informational uncertainty, if the social stigma surrounding strategic default becomes less severe and if the perceptions-reality gap between ex-ante and ex-post fear of financial backlash becomes public knowledge, it may no longer be in the lenders' and policyholders' best interests to follow a policy of informational opacity. ${ }^{21}$ At that point, lenders/policymakers will want to both ratchet up the long-lasting penalties associated with strategic mortgage default and promote as heavily as possible that these new, more severe penalties exist.

\section{References}

Bicchieri, C., 2006. The Grammar of Society: The Nature and Dynamics of Social Norms. Cambridge University Press, Cambridge, UK.
Cao, H., Han, B., Hirshleifer, D., Zhang, H., 2011. Fear of the unknown: the effects of familiarity on financial decisions. Rev. Finance 15 (1), 173206.

FICO, 2011, Predicting Strategic Default, April, white paper.

Gangel, M., Seiler, M., Collins, A., 2013. Exploring the foreclosure contagion effect using agent-based modeling. J. Real Estate Finance Econ. 46 (2), 339-354.

Ghent, A., Kudlyak, M., 2011. Recourse and residential mortgage default: evidence from US states. Rev. Financ. Stud. 24 (9), 3139-3186.

Gneezy, U., Rustichini, A., 2000. A fine is a price. J. Legal Stud. 29 (1), 1-17.

Guiso, L., Sapienza, P., Zingales, L., 2013. The determinants of attitudes towards strategic default on mortgages. J. Finance 68 (4), 1473-1515.

Harding, J., Rosenblatt, E., Yao, V., 2009. The contagion effect of foreclosed properties. J. Urban Econ. 66 (3), 164-178.

Harrison, D., Seiler, M., 2015. The paradox of judicial foreclosure: collateral value uncertainty and mortgage rates. J. Real Estate Finance Econ. 50 (3), 377-411.

Lin, Z., Rosenblatt, E., Yao, V., 2009. Spillover effects of foreclosures on neighborhood property values. J. Real Estate Finance Econ. 38 (4), 387-407.

Lorenz, E., 1999. Trust, contract and economic cooperation. Camb. J. Econ. 23 (3), 301-315.

Macaulay, S., 1963. Non-contractual relationships in business: a preliminary study. Am. Sociol. Rev. 28 (1), 55-69.

Rogers, W., Winter, W., 2009. The impact of foreclosures on neighboring housing sales. J. Real Estate Res. 31 (4), 455-479.

Seiler, M., 2014. The effect of perceived lender characteristics and market conditions on strategic mortgage defaults. J. Real Estate Finance Econ. 48 (2), 256-270.

Seiler, M., Seiler, V., Lane, M., Harrison, D., 2012. Fear, shame, and guilt: economic and behavioral motivations for strategic default. Real Estate Econ. 40 (S1), 199-233.

Seiler, M., Collins, A., Fefferman, N., 2013. Strategic mortgage default in the context of a social network. J. Real Estate Res. 35 (4), 445-475.

Seiler, M., Lane, M., Harrison, D., 2014. Mimetic herding behavior and the decision to strategically default. J. Real Estate Finance Econ. 49 (4), 621-653.

Wheaton, W., G. Nechayev, 2011. Rebalancing the US Housing Market: Two Proposals, working paper, MIT.

White, B., 2010. Underwater and not walking away: shame, fear, and the social management of the housing crisis. Wake Forest Law Rev. 45, 971-1023.

White, B., 2012. Preventing strategic default: lessons from Japan. Arizona J. Int. Comp. Law 29 (2), 235-261.

Wilkinson-Ryan, T., 2010. Do liquidated damages encourage breach? A psychological experiment. Mich. Law Rev. 108 (5), 633-671.

Wilkinson-Ryan, T., Baron, J., 2009. Moral judgment and moral heuristics in breach of contract. J. Empir. Legal Stud. 6 (2), 405-423.

Wyman, O., 2010. Understanding Strategic Default in Mortgages. Experian Report.

\footnotetext{
21 Again, we are careful to clarify that we do not study the impact of strategic mortgage defaults on overall societal wealth. Such an examination would require Pareto-optimal modeling involving complex issues such as spillover effects which is far beyond the scope of the current investigation. Instead, we focus on recommendations from the perspective of policymakers who seek to minimize the incidence of strategic mortgage default.
} 